\title{
Mobile Garden: Seeding the Knowledge to Harvest the Sustainability in the School
}

\author{
Débora da Silva Baldivia ${ }^{1}$, Kátia Ávila Antunes ${ }^{1}$, Vania Tomazelli de Lima ${ }^{1}$, Bruno do Amaral Crispim ${ }^{1}$, Zefa \\ Valdivina Pereira $^{1} \&$ Valter Vieira Alves Junior ${ }^{1}$ \\ ${ }^{1}$ Faculdade de Ciências Biológicas e Ambientais, Universidade Federal da Grande Dourados, Dourados/MS, \\ Brazil \\ Correspondence: Bruno do Amaral Crispim, Faculdade de Ciências Biológicas e Ambientais, Universidade \\ Federal da Grande Dourados, Rodovia Dourados - Itahum, Km 12, Dourados/MS, CEP: 79.804-970, Brazil. \\ E-mail: brunocrispim.bio@gmail.com
}

Received: June 15, 2013 Accepted: July 17, 2013 Online Published: November 26, 2014

doi:10.5539/jsd.v7n6p175 URL: http://dx.doi.org/10.5539/jsd.v7n6p175

\begin{abstract}
This study aimed to find the prior and acquired knowledge of students along the sustainability theme reusing PET bottles for the construction of a mobile kitchen garden in the school environment. The study was developed in four steps with students of the $8^{\text {th }}$ grade of the basic education of a public school of Dourados, MS, Brazil, in the period from September to November 2011. Step 1: Application of the questionnaire (1) to evaluate the prior knowledge of the students in relation to the sustainability theme; Step 2: Application of the environmental sensitization lecture; Step 3: Mounting of the mobile kitchen garden; Step 4: Application of the final questionnaire (2). By the results obtained from the questionnaire 1, it was observed that the students present very few widespread concepts and sometimes erroneous regarding the sustainability. After analysis of the questionnaire 2 applied at the end of the study developed with the students, it was observed that there was relevance in relation to the prior knowledge of the students. According to this study, the school is the adequate environment to develop practical and simple activities such as the mobile kitchen garden with PET bottles, since besides stimulating the students to practice sustainability, it contributes satisfactorily to the formation of citizens more concerned with the environment and in the construction of knowledge.
\end{abstract}

Keywords: recycling, sustainability, environmental education, school environment

\section{Introduction}

Environmental education has been accepted in the last years as synonymous of education for the sustainable development or of education for sustainability (Pestana, 2007). According to the Brazilian Civil Code, Law 9795 of 27/04/99, environmental education is understood by processes of the environment by which the individuals and the collectivity construct social values, knowledge, abilities, attitudes and competences for the conservation of the environment, common goods, essential to the healthy quality of life and its sustainability.

In Brazil, several sustainability initiatives are already being practiced, even in the school environment, such as specific environmental education classes, projects, waste recycling, waste sorting, reusing materials, and this place, a special place to promote activities that involve community, and is an environment that plays a key role in the formation of values and habits of human life. (Gonzales, 2005).

The school environment is undoubtedly the best place to promote environmental education with children and adolescents, since it is at this age that they retain the environmental attitudes and practices (Fetter et al., 2006). However, working with environmental education has shown to be a critical task due to the difficulties with the sensitization activities for the change in the behaviour of the individuals, in the formation of knowledge, implementation of projects and mainly in the maintenance and continuity of the already existent projects (Vasconcellos, 1997; Andrade, 2000).

Despite the difficulties found in relation to the application of environmental education in the school environment, projects of garbage recycling, selective collection, reuse of materials, awareness of the adequate use of the water and energy have been developed in schools, projects, waste recycling, waste sorting, reusing materials, awareness about the proper use of water and energy have been developed in Brazilian schools however the 
implantation of kitchen garden with Poly-Ethylene Terephthalane - PET bottles is very interesting in the school environment (Burato, 2011).

The use of PET bottles as an alternative to the practice of sustainability in the school environment is an innovative and transformative idea, since many PET bottles are discarded, causing environmental pollution, thereby using orchard for mobile contributes to the reduction of environmental pollution. Since the student is stimulated to develop and disseminate sustainability practices from the reuse of this material, environmental awareness in the school space and in the community that they live by conscious habits and attitudes, besides developing the ability of teamwork (Cribb, 2010).

By taking care of the kitchen garden with PET bottles pupils acquire knowledge, because the garden can be considered a living laboratory for different learning activities, where the goal is to turn food into an educational tool, making this becomes a starting point for new discoveries. Moreover, the activities awaken them to conserve the environment and follow paths to achieve the sustainable development (Cribb, 2010; Morgado, 2006).

Burato (2011) verified the importance, impact and influence of nature on children by the cultivation in a kitchen garden in PET bottles and proved that this activity provided interest in them for environmental issues. In work done in a state school Parobé-RS, we observed that the construction of a garden at the school provided students understanding of the importance of vegetables in the diet and the need for preservation of the natural environment, giving the garden as an interactive tool for new discoveries (Fetter et al., 2006). However, environmental education seeks to program actions in the basic education trying to form conscious and committed citizens with the main concerns of the society (Serrano, 2003).

Given the above, the study aimed to observe students' knowledge before and after the construction activities of the mobile garden reusing plastic bottles and encourage sustainable food production, providing an additional option in school lunches.

\section{Methodology}

The study was developed with 27 students aged between twelve and thirteen years of the $8^{\text {th }}$ grade of the basic education of the Municipal School Armando Campos Belo in the city of Dourados - MS, Brazil, from September to November 2011 in four steps.

Step 1 - It was applied the questionnaire 1 (attached) aiming to evaluate the prior knowledge of the students on the sustainability theme.

Step 2 - It was given a lecture, which discussed the sustainability theme with the issues: reuse of materials, recycling, selective collection, composting, sowing, mobile kitchen garden of PET bottles and importance of cultivating organic vegetables at home.

Step 3 - In this step there was the development of the mobile kitchen garden. The students took PET bottles, cut them and made holes for water drainage according to our recommendations. After these procedures, vegetal soil was placed in each PET bottle and seeds of different vegetables, as lettuce, pumpkin, cucumber, parsley, chives, were sown, then the students were instructed to place their mobile kitchen garden in an airy and illuminated place and water every day in the morning.

Step 4 - In the last step of this study, the students took new PET bottles that were cut transversally to transplant the vegetable seedlings brought by the students. At the end of the transplanting, it was applied the questionnaire 2 whose questions were the same from questionnaire 1, aiming to evaluate the knowledge that the students acquired during the period of the study.

\section{Data Analysis}

The answers obtained from the questionnaires 1 and 2 applied at the beginning and at the end of the study respectively, were analyzed and the results were expressed in graphics, with the aid of the program GraphPad Prism 3.0.

\section{Results and Discussion}

In general, the results obtained by the analysis of the questionnaire 1, which evaluated the prior knowledge of the students on the sustainability theme, showed that the students presented few widespread concepts and sometimes erroneous in relation to sustainability.

In questionnaire 1, when asked to the students if they had ever heard about sustainability (Figure 1), 36\% of the students answered that they had not heard. After the development of the sensitization activities in which it was employed the current concepts related to sustainability both in theory and in practice, it was verified in the 
answers of the questionnaire 2 the percentage of $100 \%$ in the response of the students who had heard of sustainability, this showed that there was a great fixation of the knowledge when it was given the lecture and by the development of the kitchen garden.

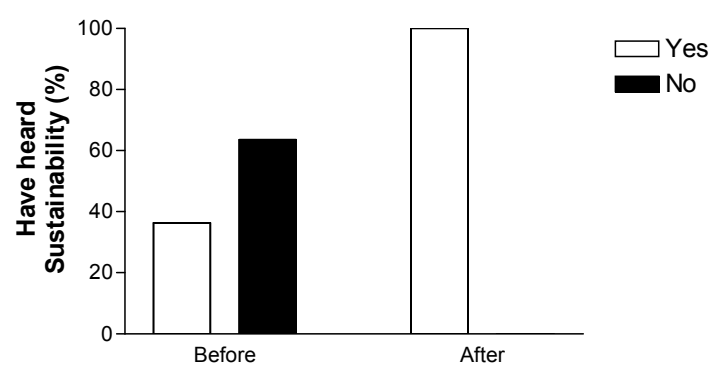

Figure 1. Questioning whether the students had heard about sustainability. Before=Responses provided before sensitization; After $=$ responses provided after sensitization

When asked about the concept of environmental sustainability (questionnaire 1) 66\% of the students said that they did not know to describe this concept, after the sensitization of the theme (questionnaire 2) this percentage dropped to $13 \%$, and it could be noticed that the activity developed in the school was significant for the comprehension of this theme.

Based on this report, it can be described the deficiency in the transmission of information that concerns environmental sustainability mainly in the school, which is a privileged and perfect environment for the transmission and discussion of the knowledge. According to UNESCO (2002), education for the sustainable development is emergent, but this dynamic concept comprises a new vision of education that aims to enable people of all ages to assume responsibilities and create a sustainable future.

When asked (questionnaire 1 and 2) by which communication media they heard of sustainability (Figure 2), the most common communication media were: Television (68\%) and (88\%), followed by school (4\%) and (68\%), internet $(12 \%)$ and $(44 \%)$, newspaper $(0 \%)$ and $(16 \%)$, and others $(8 \%)$ and $(16 \%)$, respectively.

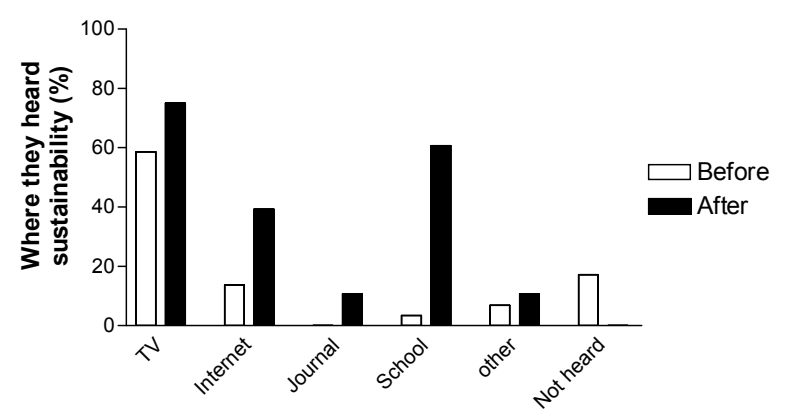

Figure 2. Which communication media the students had heard about sustainability. Before=Responses provided before sensitization; After $=$ responses provided after sensitization

From the data obtained, it is verified that the students acquired the knowledge transmitted by the researchers and there was a greater perception related to the communication media regarding issues related to environmental sustainability, since the students were more attentive to the television, school and internet that is one of the means if not the most interest for the teenagers.

According to Mellazo (2005), age, education and experiences when dealing with socio-environmental aspects, influence the environmental perception of the individuals, thus, there is the need to increase the information media and the access to current polemic themes such as sustainability, where the school plays an inductive role of the public power in the educational contents, and there is the need for further dissociation between these themes so that together with the society new possible paths can be found to alter the current situation of the socio-environmental degradation. 
When asked if they agreed that sustainability has as main objective the preservation of the environment and its natural resources (Figure 3), in questionnaire 1 we obtained $80 \%$ of the students responses saying yes and $97 \%$ in questionnaire 2. The promotion of the growth of the environmental awareness, expands the possibility of the population of participating in the decision making process in the plans to be developed, besides strengthening the supervision and control of the environmental degradation agents by the population and mainly by the school community (Jacobi, 2003; Torresi et al., 2010) and this is only possible when the population has knowledge on sustainability and environment.

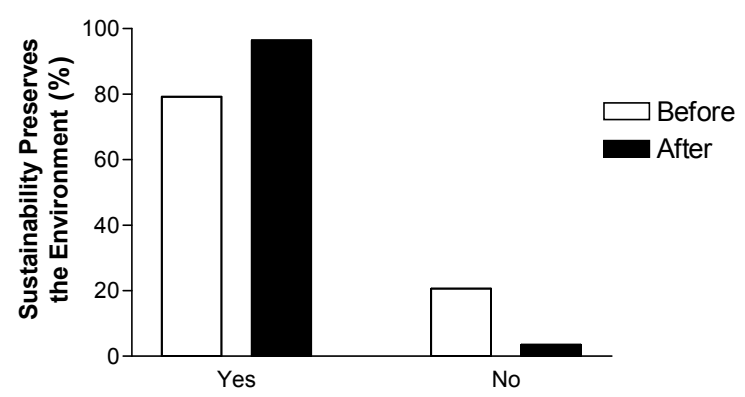

Figure 3. Responses related whether sustainability had relationship with the preservation of the environment and natural resources. Before $=$ Responses provided before sensitization; After $=$ responses provided after sensitization

When asked (questionnaire 1 and 2) if they agreed that consumerism generates an economical, social and environmental impact, the students answered yes presenting $82.8 \%$ and $93 \%$ respectively (Figure 4 ).

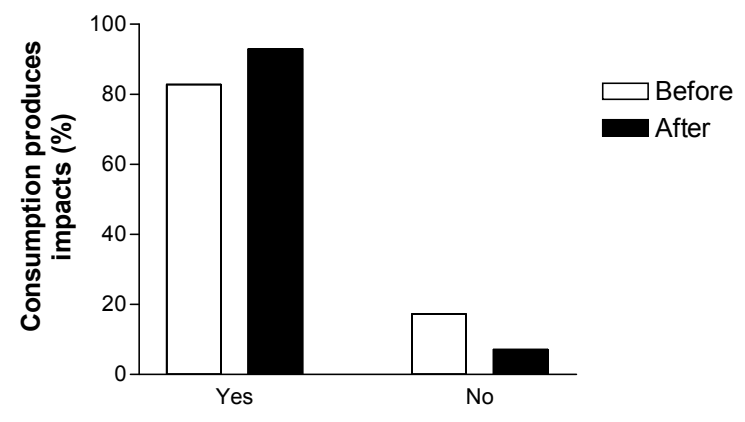

Figure 4. Consumerism generates socio-environmental impact. Before=Responses provided before sensitization; After $=$ responses provided after sensitization

After the explanation and the performance of the literal exposure of the issues addressed, the students were aware and could notice that consumerism is becoming a great problem currently, and is considered as the disease of the XXI century, this could be verified by Pires (2009) who reports that consumerism can be compared to an infection with high difficulty to be healed.

In relation to what to do to practice sustainability (Figure 5), it could be observed that in the beginning of the study, the students had the conception that it is necessary to recycle, save water, electricity and food, besides separate the garbage and reuse PET bottles and at the end of the study the data still remained positive, but some students still had doubts in relation to the issue raised. 


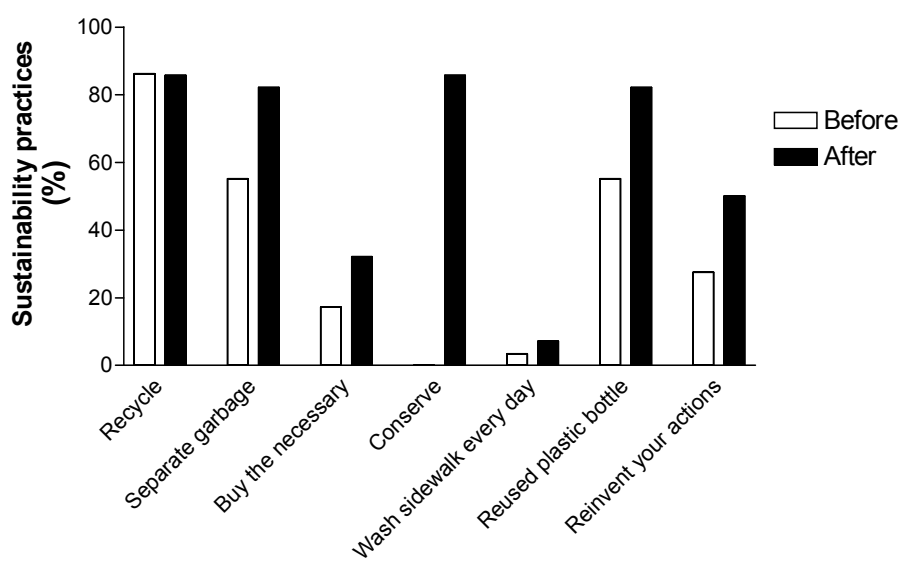

Figure 5. What to do to practice sustainability in the students perception. Before=Responses provided before sensitization; After= responses provided after sensitization

Fetter et al (2006) say that the school environment is undoubtedly the best agent to promote agro-ecological environmental education, with children and adolescents, since it is in this age that it is fixed the environmental attitudes and practices. As it is an age that better fix the knowledge, it is also in this age that the students start to make decisions and get confused and also with more doubts in some issues, which can be noticed in the results obtained and since the school is the forming and constructor of knowledge, it is the one that will work this difficulty in the students.

When the students were asked if they believed or not that education has great power to make the world more sustainable, $52 \%$ said yes, and after the activities it could be noticed an increase of $30 \%$ in relation to the initial perception (Figure 6). Based on these data, we report that from the basis that the students had on sustainability in the theoretical classes and with the implementation of the mobile kitchen garden, they started to believe that school can indeed make the world more sustainable. The mounting and organization of the kitchen garden was a moment where the students were able to practice a little of what they learned during the sensitization work. This practice is fundamental for the students to develop their creativity and notice that it is possible to make the world more sustainable. This attitude make them more environmentally responsible and we have to motivate ourselves to take this to school, since these concepts and ideals of life should be aggregated in the education so that we can have a more sustainable future.

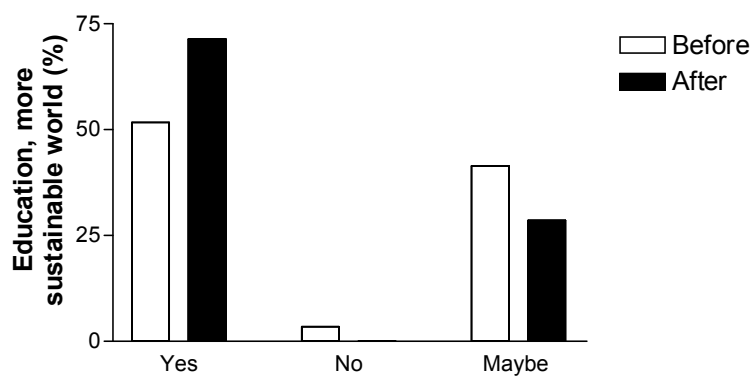

Figure 6. Education is a way to make the world more sustainable. Before=Responses provided before sensitization; After $=$ responses provided after sensitization

At the end of the questionnaire it was asked to the students to cite what they did to practice sustainability in their day to day and many of them answered that they separate the garbage and save water and when asked to cite products generated by the sustainability, several students answered "mobile kitchen garden", this implies the learning that they achieved and that they are aware that it is possible to execute some sustainability practices such as the mobile kitchen garden. 
From the mobile kitchen garden developed in the school, the students could relate much more the content seen in the classroom with the practical applications, showing awareness on the importance of vegetables and reuse of materials in order to be more careful with the environment, enabling more healthier food habits and the vision of using the resources that are often seen as "garbage" to enjoy the kitchen garden as a complement for the feeding at home or at school.

\section{Conclusions}

The application of the sustainability theme together with the application of the construction of a mobile kitchen garden using PET bottles in a public school aroused the interest of the students in relation to the environmental issue regarding the sustainable development and contributes to the construction of the knowledge.

The students acquired new perceptions on the environment where they live and the construction of knowledge influenced them in their thinking and attitudes towards life care. It can be noticed that the students were engaged in the mounting of the kitchen garden and throughout its development, by this behaviour it was noted that the activities developed enabled the comprehension by the students of the issues of environmental care and preservation, creating a responsible relationship between them and the kitchen garden and by the accompaniment of the activities.

\section{Acknowledgement}

The authors would like to thank the direction and the teacher of Sciences of the Municipal School Armando Campos Belo of Dourados/MS for the opportunity to carry out the project with the students of the $8^{\text {th }}$ grade of 2011.

\section{References}

Andrade, D. F. (2000). Implementação da Educação Ambiental em escolas: uma reflexão. In: Fundação Universidade Federal do Rio Grande. Revista do Mestrado em Educação Ambiental, v. 4.

Buratto, A. P., Dalpasquale, M., Lopes, A. C., Cortoli, C., \& Ferreira, E. S. (2011). Hortas em Garrafas PET: Uma Alternativa para a Educação Ambiental e Sustentabilidade. Synergismuss cyentifica. UFPR, Pato Branco.

Capra, F. (2005). Development and Sustainability. www.ecoliteracy.org. Managing Public Forests: Understanding the Role of Collaborative Planning. Environmental Management, 22(5), 767-776.

Cribb, S. L. S. P. (2010). Contribuições da Educação Ambiental e Horta Escolar na Promoção de Melhorias ao Ensino, à Saúde e ao Ambiente. RENPEC - Ensino, Saúde e Ambiente, 3(1), 42-60.

Fetter, S. I., Müller, J., \& Silva, M. C. (2006). Horta escolar: teoria e prática para uma vida saudável. Educação ambiental na Escola estadual João Mosmann/Parobé/SC. Revista Brasileira de Agroecologia, 1(1), 1053-1055.

Forlin, F. J., \& Faria, J. A. F. (2002). Considerações Sobre a Reciclagem de Embalagens Plásticas. Polímeros, 12(1), 50-60. http://dx.doi.org/10.1590/S0104-14282002000100006

Formigoni, A., \& Rodrigues, Ê. F. (2009). A Busca pela Sustentabilidade do PET, através da Sustentabilidade da Cadeia de Suprimentos. Key Elements for a Sustainable World: Energy, Water and Climate Change, 1, 20-22.

Gonzalez, E. G. (2005). Interdisciplinaridade e Educação Ambiental: Explorando novos territórios epistêmicos. Pesquisa e Desafios, 1, 119-133.

Jacobi, P. (2003). Educação ambiental, cidadania e sustentabilidade. In: Cadernos de Pesquisa. 118:189-205. São Paulo: Fundação Carlos Chagas/Autores Associados. http://dx.doi.org/10.1590/S0100-15742003000100008

Mellazo, G. C. (2005). A percepção ambiental e educação ambiental: uma reflexão sobre as relações interpessoais e ambientais no espaço urbano. Olhares \& Trilhas. Uberlândia, 6(6), 45-51.

Mueller, C. F. (2005). Meio-ambiente e Produtividade. Retrieved April 30, 2011, from http://pessoal.facensa.com.br/girotto/files/Logistica_de_Distribuicao/logistica_reversa.pdf

Pestana, A. P. S. (2007). Educação Ambiental e a Escola, uma ferramenta na gestão de resíduos sólidos urbanos. Retrieved from http://www.cenedcursos.com.br/educacaoambiental-e-a-escola.html

Pires, R. (2009). Consumismo - A Doença do Século XXI. Revista Nossa gente especial, 30(3), 7-7.

Serrano, C. M. L. (2003). Educação Ambiental e Consumerismo em Unidades de Ensino Fundamental de Viçosa-MG. 2003. 91f. Tese (Doutorado em Magister Scientiae) - Programa de Pós Graduação em Ciência 
Florestal, Universidade Federal de Viçosa, Viçosa. 2003.

Torresi, S. I., Pardini, V. C. L., \& Ferreira, V. F. (2010). O que é sustentabilidade? Quím. Nova, 33(1), 1-1. http://dx.doi.org/10.1590/S0100-40422010000100001

Unesco. (2002). Education for Sustainability - From Rio to Johannesburg: Lessons learnt from a decade of commitment. Paris, UNESCO Education Sector.

Vasconcellos, H. S. R. (1997). A pesquisa-ação em projetos de Educação Ambiental. In: PEDRINI, A. G. (org). Educação Ambiental: reflexões e práticas contemporâneas. PETrópolis, Vozes.

\section{Copyrights}

Copyright for this article is retained by the author(s), with first publication rights granted to the journal.

This is an open-access article distributed under the terms and conditions of the Creative Commons Attribution license (http://creativecommons.org/licenses/by/3.0/). 